\title{
KEANEKARAGAMAN, KERAPATAN, DAN DOMINANSI CACING TANAH DI BENTANG ALAM PEGUNUNGAN ARFAK
}

\author{
The Diversity, Density, and Dominancy of Earthworm \\ at the Arfak Mountain Landscape
}

\author{
Rini Elisabeth Mambrasar, Keliopas Krey, Sita Ratnawati* \\ Program Studi Biologi, Fakultas Matematika dan Ilmu Pengetahuan Alam Universitas Papua \\ Manokwari, Manokwari 98314, Indonesia
}

*Korespondensi: itta.sita@gmail.com

\begin{abstract}
ABSTRAK
Cacing tanah memiliki peran ekologis yang sangat esensi dalam tanah. Dalam kondisi alamiah keanekaragaman, kerapatan dan dominansi spesies cacing tanah sangat dipengaruhi oleh letak geografis, kondisi biotik dan abiotik habitat, termasuk iklim. Tujuan penelitian ini untuk mengetahui keanekaragaman, kerapatan dan dominansi spesies cacing tanah di bentang alam Pegunungan Arfak. Pengambilan sampel dilakukan di empat habitat berbeda mewakili dataran rendah hingga dataran tinggi yaitu Laguna Kabori, Sungai Prafi, Danau Anggi Giji dan Sungai Iray Anggi. Total 56 individu diidentifikasi menjadi tujuh spesies mewakili tiga famili yaitu Lumbricidae, Eudrilidae, dan Megascolecidae berdasarkan ciri-ciri morfologi antara lain: bentuk tubuh, panjang tubuh, jumlah segmen, letak dan warna klitelum, permukaan kulit, prostomium, gerakan, lubang dorsal dan warna tubuh. Hasil analisis terhadap faktor abiotik menunjukan bahwa suhu, kelembaban dan $\mathrm{pH}$ merupakan kunci penting bagi distribusi, keanekaragaman, kelimpahan dan dominansi spesies cacing tanah di bentang alam Pegunungan Arfak.
\end{abstract}

Keywords: Ekologi, Morfologi, Annelida, Arfak, Papua Barat

\section{PENDAHULUAN}

Cacing tanah termasuk organisme tanah yang sangat fenomenal karena dengan penyebarannya yang cepat serta kemampuan kompetisi tinggi mampu membuat taksa ini mendominasi setiap relung habitat tersesterial di dalam tanah. Cacing tanah tergolong ke dalam Filum Annelida ordo Oligochaeta dengan tubuh yang bersegmen (Simandjuntak \& Walujo, 1982).

Total 55 spesies cacing tanah telah dikatehui dari Indonesia (Suin, 1982). Beberapa spesies dari pulau Sumatera misalnya Pheretima heterochaeta, Pheretima darnliensis, Planapheretima moultoni, Friderica bulbosa, dan Friderica sp. Beberapa peran utama cacing tanah diantaranya adalah memperbaiki struktur tanah, pembentukan agregat dan pori-pori di dalam tanah, meningkatkan daya serap air di dalam tanah, menstabilkan suhu tanah dan dapat meningkatkan aerasi tanah. Perannya yang cukup banyak terhadap tanah menjadikan taksa hewan ini dimanfaatkan dalam upaya rehabilitasi dalam hal ini untuk memperbaiki lahan-lahan yang rusak (Gracia \& Fragoso, 2002). Beberapa spesies cacing tanah yang telah diketahui manfaatnya dalam kehidupan yaitu Pontoscolex corethrurus, Megascolex spp. dan Drawida sp (Dahelmi, 1984).

Penelitian tentang spesies cacing tanah di wilayah Papua Barat belum pernah dilakukan. Penelitian cacing yang sudah pernah dilakukan di Papua Barat, yaitu di Pegunungan Arfak. Penelitian ini berhasil mengindetifikasi dua spesies cacing Nematoda, Gnathostoma hispidun 
dan Hyostrongylus rubidus, yang menginfeksi lambung babi (Permadi et.al., 2012).

Danau Anggi Pegunungan Arfak termasuk dataran yang tinggi. Daerah ini sering mengalami erosi dengan tingkat kehilangan tanah dapat mencapai satu meter atau lebih (Marshall \& Beehler, 2012). Sedangkan Laguna Kabori dan sungai Prafi yang terletak di dataran rendah dekat kaki Pegunungan Arfak merupakan unit bentang alam penting di Pegunungan Arfak yang perlu dipelajarai organisme tanahnya seperti cacing.

Faktor abiotik sangat mempengaruhi keberadaan dan kepadatan populasi cacing tanah (Suin, 1997). Ketinggian tempat (altitud), suhu, kelebaban, jenis tanah, dan faktor abiotik lainnya diduga menjadi faktor pembatas keberadaan cacing tanah di bentang alam Pegunungan Arfak. Fenomena ekologi (gradien altitud) berkaitan dengan diversitas spesies, populasi dan habitat preferensi merupakan permasalahan penelitian ini. Secara eksklusif hubungan ekosistem dan komunitas Annelida mengandung nilai penting konservasi sehingga diperlukan penelitian ini.

Penelitian ini bertujuan untuk mengetahui keanekaragaman, kerapatan, dan dominansi spesies cacing tanah (Annelida) pada gradien altitud di bentang alam Pegunungan Arfak. Selain itu faktor lingkungan abiotik dan biotik lainnya yang mempengaruhi ekologi taksa ini juga diteliti.

\section{METODE}

\section{Metode Pengambilan Sampel}

Penelitian ini merupakan penelitian dasar lapangan (Field basic research). Pengambilan sampel menggunakan design stratifies random sampling (sampel acak terstrata), dalam hal ini didesain stratifikasi yang jelas, lengkap, dan mutual eksklusif. Terdapat strata yang menjadi fokus sampling yaitu laguna dataran rendah, danau dataran tinggi, sungai dataran redah dan sungai dataran tinggi. Laguna Kabori dan Sungai Prafi mewakili strata dataran rendah, sedangkan Danau Anggi Giji dan Sungai Iray Anggi mewakili strata dataran tinggi.

\section{Peralatan}

Alat yang digunakan adalah GPS, termohigrometer, cangkul, sekop kecil, plastic sampel, botol sampel, karet gelang, wadah plastik kertas label, tali raffia, silet, penggaris, jarum pentul, pinset, loop, papan perentang, cawan petri, meteran gulung, mikroskop binokuler, kamera digital (Nikon Coolpix L 27), dan alat tulis menulis. Bahan yang digunakan adalah: Aquades, Alkohol 70\%.

\section{Prosedur Penelitian}

Teknik Pengambilan, Pengawetan dan Identifikasi Sampel Cacing

- Pengambilan sampel cacing dilakukan dengan hand sorting methode (sorting dengan tangan), dalam plot berukuran $30 \mathrm{x}$ $30 \mathrm{~cm}$. Plot pengambilan sampel diletakkan secara acak pada setiap stratifikasi yang telah ditentukan.

- Plot berukuran $30 \quad$ x $30 \quad \mathrm{~cm}$ dibuat menggunakan tali raffia sebanyak 15 plot ditempatkan pada dua lokasi berbeda disetiap stratifikasi. Jadi jumlah plot yang dibuat adalah 120 plot.

- Tanah digali menggunakan sekop kecil atau cangkul dan diukur menggunakan penggaris dengan kedalaman $20 \mathrm{~cm}$ dari permukaan tanah. Kemudian cacing tanah yang diperoleh dimasukkan ke dalam plastik sampel lalu diikat menggunakan karet gelang, selanjutnya diberi label.

- Pengukuran faktor abiotik seperti suhu dan kelembaban (termohigrometer), ketinggian tempat (GPS), $\mathrm{pH}$ tanah dan keadaan cuaca saat pengambilan sampel dan hasilnya di catat pada buku catatan lapangan.

- Seluruh sampel dibawa ke Laboratorium Zoologi FMIPA, Universitas Papua untuk proses pengawetan dan identifikasi. Sampel cacing tanah dikeluarkan dari plastik sampel, lalu dibersihkan kemudian dihitung jumlah spesies dan jumlah individu pada setiap masing-masing plot.

- Sebelum melakukan proses pengawetan, cacing tanah yang telah dibersihkan dicatat morfologinya. Bagian morfologi yang diamati yaitu: bentuk tubuh, panjang total tubuh, jumlah segmen, klitelum dan warna klitelum, permukaan kulit, prostomium, lubang dorsal, warna tubuh dorsal dan ventral, warna tubuh anterior dan posterior (Blackmore, 2007 disitasi Nilawati et al., 2014). 
- Untuk melakukan proses pengawetan cacing tanah yang telah dibersihkan direntangkan memanjang dalam wadah plastik yang telah diisi Alkohol 70\% untuk mematikan cacing tersebut.

- Kemudian dilakukan proses pembedahan. Tubuh cacing diletakkan di atas papan perentang lalu dibedah dengan menggunakan silet dan bantuan pinset untuk melihat bagian dalam tubuhnya dengan menggunakan mikroskop binokuler. Bagian dalam tubuh yang dilihat yaitu: mulut, gizzard, vesikula seminalis, spermateka, jantung, (Blakemore, 2007 disitasi Nilawati et al., 2014). Proses identifikasi dilakukan mengacu pada buku Edward \& Lofty (1977) dan Easton (1979).

- Sampel tanah juga dianalisa dengan standar analisa tanah di Laboratorium Tanah Fakultas Pertanian Unipa.

\section{Analisa Data}

Analisa data ekologi meliputi keanekaragaman, kelimpahan relatif, dan dominansi spesies. Indeks yang digunakan dalam analisa ini adalah indeks keanekaragaman Shannon Wiener (H'), indeks kemerataan Evenness (E) (Magurran, 1988), kelimpahan relatif (KR) (Cox, 1996), dan dominansi Simpson (D) (Simpson, 1949 disitasi Magurran, 1988).

\section{HASIL DAN PEMBAHASAN Identifikasi Spesies}

Total tujuh spesies cacing tanah telah diidentifikasi dari empat habitat berdasarkan gradien altitud di Pegunungan Arfak. Sebanyak empat spesies dikoleksi dari Laguna Kabori (9-11 m dpl), satu spesies dari Sungai Prafi (196-230 m dpl), empat spesies dari Danau Anggi Giji (19491953 m dpl) dan dua spesies dari Sungai Iray Anggi (1971-1972 m dpl). Berdasarkan deskripsi meristik dan morfometrik, terdapat 3 famili cacing tanah yaitu Lumbricidae, Eudrilidae dan Megascolecidae (Tabel 1), sedangkan profil setiap spesies dapat dilihat pada Gambar 1-7.

Berdasarkan gradien altitud ditemukan fenomena distribusi yang sangat menarik yaitu spesies cacing tanah dari famili Megascolecidae terdistribusi hanya pada gradien altitud tinggi (Danau Anggi dan Sungai Iray Anggi). Walaupun L. rubellus tercatat umum di gradien altitud rendah (Laguna Kabori dan Sungai Prafi) namun ditemukan juga pada altitud tinggi di Danau Anggi Giji.

Tabel 1. Hasil Identifikasi Spesies Cacing Tanah pada beberapa habitat

\begin{tabular}{|c|c|c|c|c|}
\hline \multirow[b]{2}{*}{$\begin{array}{l}\text { Famili/ } \\
\text { Spesies }\end{array}$} & \multicolumn{4}{|c|}{$\begin{array}{l}\text { Habitat \& Jumlah } \\
\text { Individu }\end{array}$} \\
\hline & 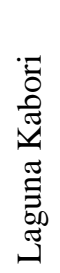 & 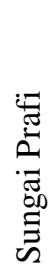 & 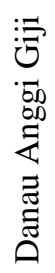 & 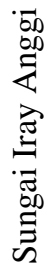 \\
\hline Lumbricidae & & & & \\
\hline Lumbricus terrestris & 2 & - & - & - \\
\hline $\begin{array}{l}\text { Lumbricus rubellus } \\
\text { Eudrilidae }\end{array}$ & 3 & - & 4 & - \\
\hline Eudrilus sp. & 1 & - & - & - \\
\hline $\begin{array}{l}\text { Eudrilus eugeinae } \\
\text { Megascolicidae }\end{array}$ & 1 & 19 & - & - \\
\hline Polypheretima bifaria & - & - & 5 & 8 \\
\hline Polypheretima mertoni & - & - & 7 & 4 \\
\hline Archipheretima sp. & - & - & 2 & - \\
\hline Jumlah Spesies & 4 & 1 & 4 & 2 \\
\hline
\end{tabular}

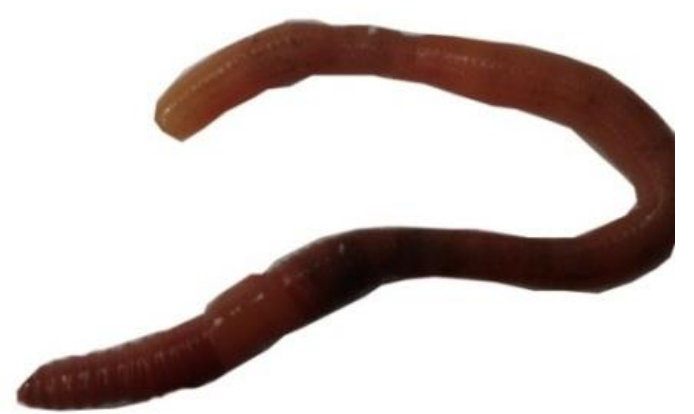

Gambar 1. Lumbricus terrestris

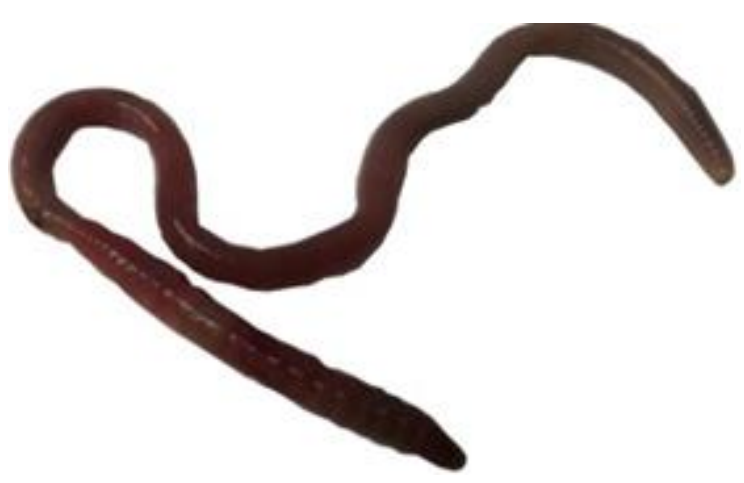

Gambar 2. Lumbricus rubellus 


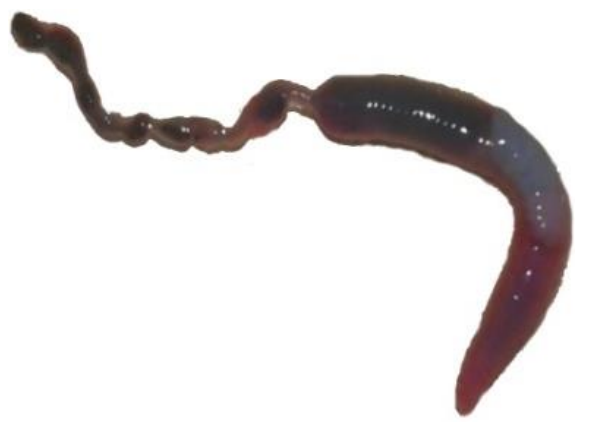

Gambar 3. Eudrilus sp.

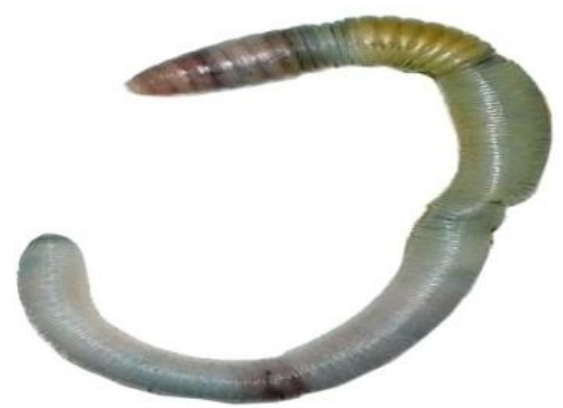

Gambar 4. Eudrilus eugeinae

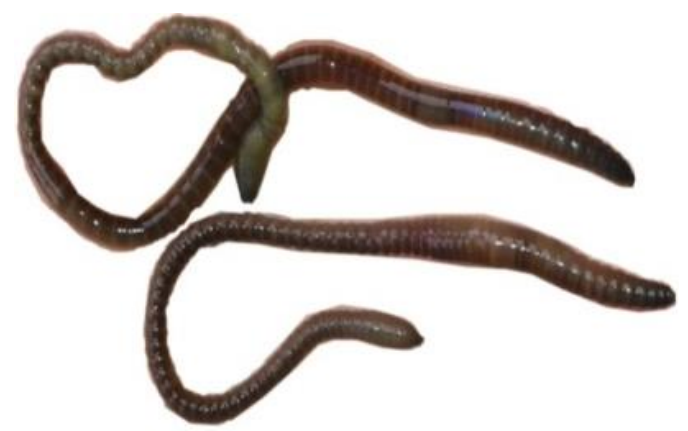

Gambar 5. Polypheretima bifaria

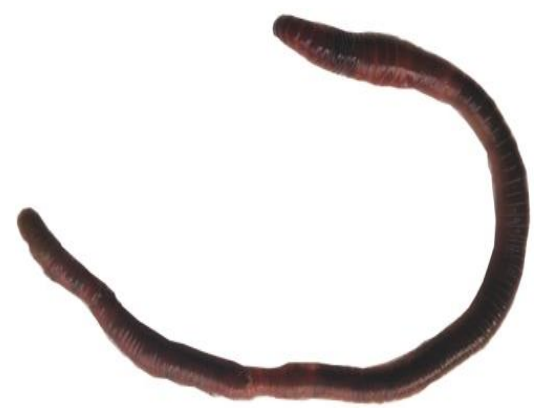

Gambar 6. Polypheretima mertoni

\section{Deskripsi Spesies dari Tiga Famili Cacing Tanah yang ditemukan}

Tiga Famili, Lumbricidae, Eudrilidae dan Megascolecidae dengan tujuh spesies telah dideskripsi dengan baik dalam penelitian ini. Dua spesies yang diidentifikasi mewakili Famili Lumbricidae adalah Lumbricus terrestris dan Lumbricus rubellus. Famili Eudrilidae diwakili

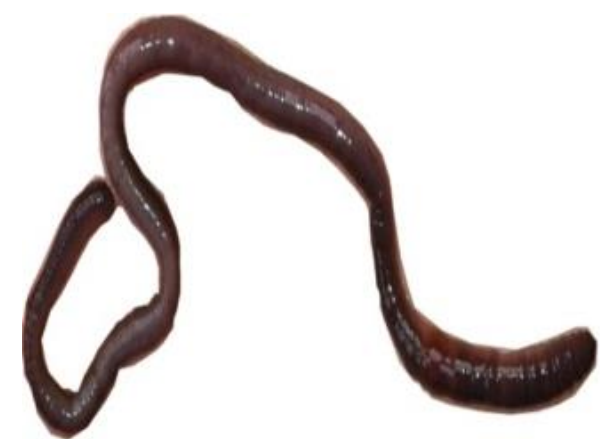

Gambar 7. Archipheretima sp.

oleh dua spesies yaitu Eudrilus sp. dan Eudrilus eugeinae, sedangkan famili Megascolecidae diwakili tiga spesies dari genus Polypheretima yakni $P$. bifaria, dan P. mertoni dan satu spesies belum teridentfikasi dari genus Archipheretima. Perbedaan morfologi antara spesies serta karakterisasi ciri morfologi dan anatomi masingmasing spesies cacing tanah yang ditemukan dalam penelitian ini dirangkum dalam Tabel 2-4.

\section{Lumbricus terrestris}

Ciri-ciri morfologi: berwarna coklat merah pada bagian dorsal, warna kuning krem pada bagian ventral, warna coklat merah pada bagian anterior dan warna orange kekuningan pada bagian posterior. Rata-rata panjang tubuh 4-7.6 $\mathrm{cm}$ dengan jumlah 112-114 segmen dan Klitelum berwarna orange. Habitat: Laguna Kabori (S: 0058'47.6”, E: $133^{\circ} 01^{\prime} 15^{\prime}$ '.5), altitud $11 \mathrm{~m} \mathrm{dpl}$. Suhu tercatat $31^{\circ} \mathrm{C}$, kelembaban tanah $90 \%$, pH 6.3 agak masam, dan tekstur tanahnya tanah berpasir. Spesies cacing ini berasal dari Eropa dan sudah banyak tersebar sampai di seluruh dunia (Khairuman \& Amri, 2010).

\section{Lumbricus rubellus}

Ciri-ciri morfologi: berwarna merah coklat atau merah keunguan pada bagian dorsal, warna krem pada bagian ventral, ungu kemerahan pada bagian anterior, warna kekuningan pada bagian posterior. Klitelum jelas dan berwarna krem coklat. Klitelum tampak seperti penggembungan atau perbesaran dari beberapa segmen dan warna lebih terang dari segmen tubuh lainnya. Klitelum terletak pada segmen ke 26.27-32. Panjang tubuh 7.9-14.5 cm, dan jumlah segmen 95-120 segmen.

Habitat: Laguna Kabori (altitude $11 \mathrm{~m} \mathrm{dpl}$ ) dan Danau Anggi Giji (altitud 1973 m dpl). Suhu 
di Laguna Kabori jauh lebih hangat $\left(31^{\circ} \mathrm{C}\right)$ dibandingkan di Danau Anggi Giji $\left(25^{\circ} \mathrm{C}\right)$. Sedangkan kelembaban jauh lebih tinggi di Laguna Kabori (90\%) dan $70 \%$ lebih rendah di Danau Anggi Giji. Tercatat $\mathrm{pH}$ agak masam pada kedua lokasi (5.6 dan 6.3). Tekstur tanah pada kedua lokasi sangat berbeda yakni tanah berpasir di Laguna kabori dan lempung liat berdebu di Danau Anggi Giji. Distribusi asli spesies ini adalah Eropa dan Kepulauan Inggris, tetapi spesies ini telah menyebar di seluruh dunia saat ini dan mampu bertahan hidup pada habitat dan keadaan lingkungan yang cocok (Khairuman \& Amri, 2010).

\section{Eudrilus sp.}

Ciri-ciri morfologi: berwarna merah coklat pada bagian dorsal, hitam pada bagian anterior, krem pada bagian ventral dan hitam pada bagian posterior, segmen jelas pada klitelum berwarna putih dengan jumlah segmen 7 segmen, panjang tubuh $5.4 \mathrm{~cm}$, dan jumlah 171 segmen. Dipastikan tidak dapat diidentifikasi sampai tingkat spesies karena tidak adanya karakter yang sesuai dengan kunci identifikasi yang tersedia.

Habitat: Laguna Kabori dengan kisaran ketinggian tempat $10 \mathrm{~m}$ dpl. Suhu $31^{\circ} \mathrm{C}$, dengan kelembaban 90\%, dan pH 6.3 agak masam, tekstur tanahnya berpasir.

\section{Eudrilus eugeinae}

Ciri-ciri morfologi: berwarna merah keunguan pada bagian dorsal, ventral krem, merah kecoklatan pada bagian anterior dan coklat abu-abu hingga merah kecoklatan pada bagian posterior. Segmen jelas pada klitelum berwarna kuning orange dengan delapan segmen. Panjang tubuh 5-7.8 cm, dan jumlah 154-211 segmen.

Habitat: Laguna Kabori (altitud $9 \mathrm{~m} \mathrm{dpl}$ ) dan Sungai Prafi (230 m dpl). Suhu di Laguna Kabori jauh lebih hangat $\left(32^{\circ} \mathrm{C}\right)$, dibandingkan suhu di Sungai Prafi yang cukup dingin $\left(28^{\circ} \mathrm{C}\right)$. Kelembaban jauh lebih tinggi di Laguna Kabori 90\% di bandingkan di Sungai Prafi 84\%. Tercatat pH agak masam pada pada kedua lokasi ( $\mathrm{pH} 6.3$ dan 6.5) dengan tekstur tanah berpasir di Laguna Kabori dan lempung liat berpasir di Sungai Prafi. Spesies Eudrilus eugeinae berasal dari dataran tropis Benua Afrika yang telah dikembangkan untuk keperluan ternak diberbagai dunia termasuk Indonesia (Satchell, 1995).

\section{Polypheretima bifaria}

Ciri-ciri morfologi: bentuk tubuh silindris dan berwarna agak kehitaman pada bagian dorsal, anterior hitam, ventral coklat, sedangkan posterior berwarna kehitaman. Segmen jelas pada klitelum berwarna coklat krem. Panjang tubuh berkisar 9.5-10 cm, dengan 108-110 segmen.

Habitat: Danau Anggi Giji dan Sungai Iray Anggi (altitude 1949-1973 m dpl). Suhu di Danau Anggi Giji dan Sungai Iray Anggi sangat dingin, $21-25^{\circ} \mathrm{C}$. Kelembaban di kedua lokasi $70 \%$, dan $\mathrm{pH}$ tercatat agak masam pada kedua lokasi (pH 5.6 dan 6.4), dengan tekstur tanah masing-masing lempung liat berdebu dan pasir berlempung. Distribusi cacing tanah dari genus Polypheretima tersebar luas di wilayah Asia Tenggara. Genus Polypheretima terdapat juga di wilayah Sumatera bagian tengah, seluruh wilayah Sulawesi dan Kalimantan bahkan sampai ke wilayah New Guinea dan kepulauan Aru (Easton, 1979).

\section{Polypheretima mertoni}

Ciri-ciri morfologi: bentuk tubuh silindris dan berwarna merah coklat tua pada bagian dorsal, warna coklat merah pada bagain anterior, warna pucat abu-abu pada bagian ventral, warna coklat pada bagaian posterior. Segmen jelas pada klitelum berwarna coklat krem panjang tubuh 4.5-9.7 cm, dan jumlah 79-82 segmen.

Distribusi cacing tanah $P$. mertoni terdapat juga di wilayah Sumatera bagian tengah seluruh wilayah Sulawesi dan Kalimantan bahkan sampai ke wilayah kepulauan Aru (Easton, 1979).

\section{Archipheretima sp.}

Ciri-ciri morfologi: bentuk tubuh silindris dan berwarna merah coklat tua pada bagian dorsal, warna coklat merah pada bagain anterior, ventral warna pucat, dan posterior warna coklat. Segmen jelas pada klitelum berwarna coklat, panjang tubuh 9.5-14 cm, dan jumlah 103-152 segmen. Dipastikan spesies genus ini yang ditemukkan di Danau Anggi Giji tidak dapat teridentifikasi sampai tingkat spesies karena tidak 
adanya karakter yang sesuai dengan kunci $\mathrm{pH}$ tercatat agak masam (pH 5.6), tekstur identifikasi yang tersedia. tanahnya lempung liat berdebu. Distribusi cacing

Habitat: Danau Anggi Giji (altitud 1953 m tanah Archipheretima sp. terdapat juga di seluruh dpl). Suhu $25^{\circ} \mathrm{C}$ dengan kelembaban cukup 70\%, wilayah Kalimantan dan Filipina (Easton, 1979).

Tabel 2. Ciri-ciri Morfologi Lumbricus spp.

\begin{tabular}{lll}
\hline Ciri Morfologi & L. terrestris & L. rubellus \\
\hline Bentuk & pipih & pipih \\
Panjang & $4-7,6 \mathrm{~cm}$ & $7,9-14,5 \mathrm{~cm}$ \\
Jumlah segmen & $112-114$ & $96-127$ \\
Letak klitelum & 31 & 26 \\
Warna klitelum & orange & krem coklat mengkilat \\
Permukaan Kulit & licin & licin \\
Prostomium & epilobus & epilobus \\
Gerakan & lambat & lambat \\
Lubang Dorsal & $13 / 14$ & $13 / 14$ \\
Warna tubuh: & & \\
Dorsal & coklat merah & coklat kemerahan \\
Anterior & coklat merah & ungu kemerahan \\
Ventral & kuning krem & krem \\
Posterior & orange kekuningan & kekuningan \\
\hline
\end{tabular}

Tabel 3. Ciri-ciri Morfologi Eudrilus spp.

\begin{tabular}{lll}
\hline Ciri Morfologi & Eudrilus sp. & Eudrilus eugeinae \\
\hline Bentuk & pipih & pipih \\
Panjang & $5.4 \mathrm{~cm}$ & $5-7.8 \mathrm{~cm}$ \\
Jumlah segmen & 171 & $154-211$ \\
Klitelum & $14-21$ & $13-14$ \\
Warna klitelium & putih & kuning orange \\
Permukaan kulit & kasar/keras & kasar/keras \\
Prostomium & epilobus & epilobus \\
Gerakan & agak lambat & agak lambat \\
Warna tubuh : & & \\
Dorsal & merah coklat & merah keunguan \\
Anterior & hitam & merah kecoklatan \\
Ventral & krem & krem \\
Posterior & hitam & coklat abu-abu \\
\hline
\end{tabular}

Tabel 4. Ciri-ciri Morfologi Polypheretima spp. dan Archipheretima sp.

\begin{tabular}{llll}
\hline Ciri Morfologi & P. bifaria & P. mertoni & Archipheretima sp. \\
\hline Bentuk & silindris & silindris & silindris \\
Panjang & $9.5-10 \mathrm{~cm}$ & $4.5-9.7 \mathrm{~cm}$ & $9.5-14 \mathrm{~cm}$ \\
Jumlah segmen & $108-110$ & $79-82$ & $103-152$ \\
Klitelum & 16 & 14 & $17-18$ \\
Warna klitelium & coklat krem & coklat krem & coklat krem \\
permukaan kulit & agak licin & agak licin & agak licin \\
Prostomium & tanilobus & tanilobus & tanilobus \\
Gerakan & cepat & cepat & cepat \\
Lubang Dorsal & $12 / 13$ & $12 / 13$ & $12 / 13$ \\
Warna tubuh : & & & \\
Dorsal & agak kehitaman & merah coklat tua & merah coklat tua \\
Anterior & hitam & coklat merah & coklat merah \\
Ventral & coklat & pucat abu-abu & pucat abu- abu \\
Posterior & kehitaman & coklat & coklat \\
\hline
\end{tabular}




\section{Keanekaragaman Spesies Cacing Tanah}

Keanekaragaman spesies cacing tanah sangat bergantung pada faktor biotik dan abiotik karena dapat mempengaruhi siklus hidup dan kemampuan bertahan hidupnya. Hasil analisis menunjukkan bahwa tidak semua spesies cacing tanah tersebar merata pada semua habitat berdasarkan gradien ketinggian tempat. Setiap spesies juga menunjukkan keadaan kelimpahan dan dominansi yang bervariasi pada setiap gradien ketinggian. L. rubellus (Lumbricidae) ditemukan terdistribusi di dua tipe habitat berbeda yaitu Laguna Kabori dan Danau Anggi Giji sedangkan $P$. bifaria dan $P$. mertoni dari Family Megascolecidae masing-masing ditemukan di Danau Anggi Giji dan Sungai Iray Anggi. Nilai kelimpahan relatif spesies yang tertinggi adalah $P$. bifaria $(66.67 \%)$ yang ditemukan di Sungai Iray Anggi (Tabel 5-6).

Dalam penelitian ini tercatat suhu dan kelembaban sangat mempengaruhi distribusi spesies cacing tanah di bentang alam Pegunungan Arfak mulai dari Laguna Kabori di dataran rendah (altitud $11 \mathrm{~m} \mathrm{dpl)} \mathrm{hingga} \mathrm{Danau} \mathrm{Anggi} \mathrm{di}$ dataran tinggi, altitud $1953 \mathrm{~m}$ dpl. Suhu terendah terdapat pada habitat sungai Iray di Anggi mencapai $21.250 \mathrm{C}$ sedangkan yang tertinggi yaitu pada Laguna Kabori (320C). Kelembaban pada keempat habitat berkisar dari 84\%-90\%, kelembaban tertinggi $70 \%$ pada Danau Anggi Giji dan juga Sungai Iray dan yang terendah $90 \%$ tercatat pada tipe habitat Laguna Kabori dan Sungai Prafi. Keadaan vegetasi disetiap habitat merupakan vegetasi nonhutan. Umumnya didominasi oleh tingkat perdu dan pohon yang berukuran kecil serta semak yang tersedia di suatu habitat.

Setiap spesies cacing tanah mempunyai kisaran suhu tertentu. Suhu yang ekstrim tinggi atau rendah dapat mematikan cacing tanah. Suhu tanah dapat mempengaruhi pertumbuhan, reproduksi dan metabolisme. Tiap spesies cacing tanah memiliki kisaran suhu optimum tertentu, contonya Lumbricus rubellus kisaran suhu optimumnya $15-18^{\circ} \mathrm{C}$, Lumbricus terrestris \pm $10^{\circ} \mathrm{C}$, sedangkan kondisi yang sesuai untuk aktivitas cacing tanah pada malam hari ketika suhu tidak melebihi $10,5^{\circ} \mathrm{C}$ (Wallwork, 1970).

Tabel 5. Perbandingan Faktor Abiotik terhadap Level Keanekaragaman, Kerapatan, dan Dominansi Cacing Tanah di Bentang Alam Pegunungan Arfak

\begin{tabular}{cccccccc}
\hline No & Habitat & $\begin{array}{c}\text { Rata-rata } \\
\text { Suhu }\left({ }^{\circ} \mathrm{C}\right)\end{array}$ & $\begin{array}{c}\text { Kelembaban } \\
(\%)\end{array}$ & $\begin{array}{c}\text { Ketinggian } \\
(\mathrm{m} \text { dpl })\end{array}$ & $\mathrm{H}$ & $\mathrm{KR}$ & $\mathrm{D}$ \\
\hline 1 & Laguna Kabori & 31.5 & 90 & $10-19$ & 1.27 & 25 & 0.24 \\
2 & Sungai Prafi & 30.16 & $84-90$ & $197-230$ & 0 & 0 & 0 \\
3 & Danau Anggi Giji & 2526 & 70 & $1949-1953$ & 1.17 & 25 & 0.24 \\
4 & Sungai Iray Anggi & 21.25 & 70 & $1971-1973$ & 0.63 & 50 & 0.49 \\
\hline
\end{tabular}

Tabel 6. Analisa kelimpahan relatif dan indeks dominansi pada empat habitat

\begin{tabular}{lcccccccc}
\hline \multicolumn{1}{c}{ Spesies } & \multicolumn{2}{c}{ LK } & \multicolumn{2}{c}{ SP } & \multicolumn{2}{c}{ DAG } & \multicolumn{2}{c}{ SIA } \\
\hline & KR & D & KR & D & KR & D & KR & D \\
\hline Lumbricus rubellus & 42.86 & 0.42 & & & 13.33 & 0.13 & & \\
Lumbricus terrestris & 28.57 & 0.28 & & & & & & \\
Eudrilus eugeinae & 14.29 & 0.14 & 0 & 0 & & & & \\
Eudrilus sp. & 14.29 & 0.14 & & & & & & \\
Polypheretima bifaria & & & & & 43.33 & 0.43 & 66.67 & 0.66 \\
Polypheretima mertoni & & & & & 36.67 & 0.36 & 33.33 & 0.33 \\
Archipheretima sp. & & & & & 6.67 & 0.06 & & \\
\hline \multicolumn{1}{c}{ Rata-rata } & 25.00 & 0.24 & 0 & 0 & 25 & 0.24 & 50 & 0.49 \\
\hline
\end{tabular}

Keterangan: $\mathrm{LK}=$ laguna kabori, $\mathrm{SP}=$ sungai prafi, $\mathrm{DAG}=$ danau anggi giji, $\mathrm{SIA}=$ sungai iray anggi, $\mathrm{KR}=$ kelimpahan relatif, $\mathrm{D}=$ dominansi 
Kelembaban pada empat habitat berkisar dari $70-90 \%$. Suhu yang rendah dan habitat yang dekat dengan danau dan sungai pada ketinggian 1949-1973 mendukung tingginya kelembaban di Danau Anggi Giji dan Sungai Iray Anggi. Sebaliknya kelembaban yang terendah terdapat pada habitat Laguna Kabori. Kelembaban ideal untuk cacing tanah adalah antara 15\%-50\%, namun kelembaban optimumnya adalah antara 42\%-60\% (Rukmana, 1999). Kelembaban yang terlalu tinggi (terlalu basah) dapat menyebabkan cacing tanah berwarna pucat dan kemudian mati (Subowo et al., 2002).

Keberadaan dan kepadatan cacing tanah juga sangat ditentukan oleh $\mathrm{pH}$ (Wallwork, 1970). Hasil analisis sampel tanah yang dilakukan di Laboratorium Tanah Fakultas Pertanian Unipa menunjukkan kualitas $\mathrm{pH}$ agak masam (5.6-6.5) sehingga sangat mempengaruhi populasi dan aktivitas cacing tanah dan menjadi faktor pembatas penyebaran dan spesiesnya. Umumnya cacing tanah tumbuh baik pada $\mathrm{pH}$ sekitar 7.0 (Wallwork, 1970). Menurut Rukmana (1999) tanah pertanian di Indonesia umumnya bermasalah karena pH-nya asam. Tanah yang pH-nya asam dapat mengganggu pertumbuhan dan daya bereproduksi cacing tanah, karena ketersediaan bahan organik dan unsur hara sehingga cacing tanah relatif terbatas.

Penelitian ini menunjukkan bahwa faktor abiotik kunci bagi perkembangbiakan cacing tanah di bentang alam Pegunungan Arfak adalah kelembaban, suhu dan $\mathrm{pH}$. Tiga faktor abiotik tersebut berperan sangat penting dalam seluruh siklus hidup cacing tanah. Suhu, kelembaban, dan $\mathrm{pH}$ dapat dibandingkan dengan penelitian lainnya (Tabel 7) yang menunjukkan bahwa fenomena ekologi ini perlu dipertahankan dengan tetap menjaga kelestarian keanekaragaman ekosistem dan spesies vegetasi.

Faktor biotik juga mempengaruhi keberadaan spesies cacing tanah di habitatnya untuk dapat berkembang. Pada tanah dengan vegetasi dasarnya rapat, cacing tanah akan banyak ditemukan, karena fisik tanah lebih baik dan sumber makanan yang banyak ditemukan berupa serasah (Suin, 1982). Selain itu faktor makanan baik jenis maupun kuantitas vegetasi yang tersedia di suatu habitat sangat menentukan keanekaragaman spesies dan kerapatan populasi cacing tanah di habitat tersebut (Edward \& Lofty, 1977).

Tabel 7. Faktor abiotik terukur saat penelitian dengan perbandingan referensi

\begin{tabular}{lccccccccc}
\hline \multirow{1}{*}{ Spesies } & \multicolumn{8}{c}{ Faktor Abiotik (referensi 1-3) } \\
\cline { 2 - 10 } & \multicolumn{2}{c}{ Kelembaban $(\%)$} & \multicolumn{3}{c}{ Suhu $\left({ }^{\circ} \mathrm{C}\right)$} & \multicolumn{3}{c}{$\mathrm{pH}$} \\
\cline { 2 - 9 } & 1 & 2 & 3 & 1 & 2 & 3 & 1 & 2 & 3 \\
\hline L.terrestris & $42-60$ & 90 & 10 & - & 31 & 7.0 & - & 5.8 \\
L.rubellus & $42-60$ & $70-90$ & $15-18$ & - & $25-31$ & 7.0 & - & 6.3 \\
Eudrilus $\mathrm{sp}$. & $42-60$ & 90 & - & - & $28-32$ & 7.0 & - & 6.3 \\
E. eugeinae & $42-60$ & $87-98$ & - & - & 31 & 7.0 & - & 6.3 \\
P. bifaria & $42-60$ & 70 & - & - & $21-26$ & 7.0 & - & 6.0 \\
P. mertoni & $42-60$ & 70 & - & - & $21-26$ & 7.0 & - & 5.8 \\
Archipheretima sp. & $42-60$ & 70 & - & - & 24 & 7.0 & - & 5.6 \\
\hline
\end{tabular}

Keterangan: 1. Wallwork (1970); 2. Rukmana (1999); 3. Penelitian ini;

-: tidak ada data

\section{SIMPULAN}

Berdasarkan hasil penelitian ini maka simpulan yang diperoleh adalah tujuh spesies cacing tanah yang teridentifikasi memiliki persebaran yang tidak merata. Ternyata faktor abiotik kunci bagi distribusi, keanekaragaman, kelimpahan, dan dominansi cacing tanah di bentang alam Pegunungan Arfak adalah suhu, kelembaban dan $\mathrm{pH}$.

\section{DAFTAR PUSTAKA}

Cox, GW. 1996. Laboratory manual of general ecology. $7^{\text {th }}$ ed. Wm. C. brown Company Publisher, Dubuque: $\mathrm{x}+278 \mathrm{hlm}$.

Dahelmi. 1984. Cacing Tanah Pada Timbunan Sampah Kotamadya Padang. [Tesis]. Universitas Andalas, Padang.

Edward, CH., Lofty, JR. 1977. Biology of Earthworm. London. Chapman and Hall. 
Easton, EG 1979. A Revision of The 'Acaecate' Earthworms of The Pheretima Group

(Megascoleciodae: Oligochaeta):

Archipheretima, Metapheretima,

Plonetima, Plonapheretima,

Pleionogaster and Polypheretima.

Garcia, J. Fragoso C. 2002. Growth,

Reproduction and Activity of Earthworms Indegraded and Amended Tropical Open Mined Soils: Laboratory Assays. Applied Soil Ecology 20: 43-56.

Magurran, AE 1988. Ecological Diversity and Its

Measurement. Princetion University Press, New Jersey.

Marshall, AJ., Beehler BM. 2012. Ekologi Papua. Kartikasari, S.N. (Editor). Yayasan Pustaka Obor Indonesia dan Convervation Internasional. Jakarta.

Nilawati, I, Dahlemi, Nurdin, I. 2014. Jenis-jenis Cacing Tanah (Oligochaeta) yang Terdapat di Kawasan Cagar Alam Lembah Anai Sumatera Barat. Jurnal Biologi Universitas Andalas, 02 (03): 88-89.

Permadi, II., Damriyas I., Suratma AM. 2012. Prevalensi Cacing Nematoda Pada Babi. Jurnal Indonesia Medicus Velerinus, 01 (5): 596-606.
Rukmana, HR. 1999. Budidaya Cacing Tanah, Penerbit Kansius (Anggota IKAPI), Yogyakarta.

Simandjuntak, AK., Walujo D. 1982. Cacing tanah: Budidaya dan Pemanfaatannya. Penebar Swadaya (Anggota IKAPI). Jakarta.

Subowo, Anas I, Djajakirana G., Abdurrachman A., Hardjowigeno S. 2002. Pemanfaatan cacing tanah untuk meningkatkan produktivitas ultisol di lahan kering. J. Tanah dan Iklim 20:35-46.

Suin, NM. 1982. Cacing Tanah dari Biotop Hutan Belukar dan Kebun di Kawasan Gambung Jawa Barat. Tesis Pasca Sarjana (S2). InstitutTeknologi Bandung. Bandung (Tidak diterbitkan).

Suin, NM. 1997. Ekologi Hewan Tanah. Jakarta: Penerbit Bumi Aksara, Jakarta.

Satchell, JE. 1955. Some Aspect of Earthworm Ecology, in Soil Zoology. Edition by Kevan. London; Butterworths. PP. 138151.

Wallwork, JA. 1970. Ecology of Soil Animal. MC. Graw Hill Book, Company, London, PP. 58-74. 